\title{
Distribusi Jenis Lamun Dihubungkan dengan Sebaran Nutrien Perairan di Padang Lamun Teluk Awur Jepara
}

\author{
Ita Riniatsih \\ Departemen IImu Kelautan, Fakultas Perikanan dan IImu Kelautan, Universitas Diponegoro \\ JI. Prof. Soedarto, SH. Kampus UNDIP Tembalang, Semarang 50275 \\ Email: iriniatsih@yahoo.com
}

\begin{abstract}
Abstrak
Ekosistem padang lamun sebagai salah satu ekosistem di wilayah pesisir mempunyai produktifitas yang tinggi. Proses produksi tegakan lamun sebagai hasil fotosintesa menghasilkan biomassa lamun yang relative tinggi. Sejalan dengan proses produksi tersebut, serasah lamun yang luruh di dasar perairan sebagai detritus mengalami proses dekomposisi oleh bakteri pengurai. Proses dekomposisi ini akan menghasilkan nutrien terlarut di perairan yang kemudian akan dimanfaatkan kembali oleh lamun untuk proses produksi. Penelitian tentang kajian distribusi jenis lamun yang dihubungkan dengan sebaran nutrien perairan di padang lamun Teluk Awur Jepara telah dilakukan dengan hasil yang menunjukkan sebaran nutrient lamun di empat stasiun dengan masing masing 3 kali ulangan menunjukkan bahwa lamun jenis Thalasisia hemprichii dan Enhalus acoroides cenderung menyebar pada habitat dengan substrat pasir berlumpur dengan kandungan bahan organik yang relatif tinggi.sedangkan lamun jenis Cymodocea serrulata dan Syringodium isoetifolium lebih banyak ditemukan di habitat dengan substrat pasir halus. Hasil analisa laboratorium untuk kandungan nutrient perairan dan sedimen menunjukkan hasil yang bervariasi dengan kisaran rata-rata antara 2,006-3,276 mg/l untuk nitrat dan 0,0025 -0,0076 mg/l untuk phospat perairan serta 4,254-7,324 mg/l untuk nitrat dan 2,324-5,544 mg/l untuk phospat sedimen perairan. Indeks Keanekaragaman, Indeks Keseragaman dan Indeks Dominansi lamun menunjukan nilai rendah hingga sedang, bervariasi menurut distribusi jenis lamun yang ditemukan di lokasi penelitian.
\end{abstract}

Kata Kunci: distribusi jenis lamun, nutrient perairan, perairan Jepara

\section{PENDAHULUAN}

Ekosistem padang lamun merupakan salah satu ekosistem di wilayah pesisir yang mempunyai produktivitas primer yang relative tinggi dan mempunyai peranan yang penting untuk menjaga kelestarian dan keanekaragaman orgnisme laut. Adi (2000) ; Chute et al (2001) dan Helfman et al, (2009) menjelaskan padang lamun banyak mempunyai fungsi ekologis yang sangat penting sebagai daerah pemijahan dan asuhan bagi berbagai jenis oegnisme laut. Keaanekaragaman jenis dan biomassa perikanan pantai diantaranya sangat dipengaruhi oleh keberadaan vegetasi lamun sebagai unsur penyusun padang lamun. Banyak organisme laut yang memanfaatkan padang lamun sebagai habitat hidup. Padang lamun mempunyai fungsi sebagai daerah pemijahan, daerah mencari makan dan daerah asuhan bagi organisme laut muda yang biasanya memanfaatkan daerah pasang surut dan padang lamun sebagai tempat berlindung dan mencari makan pada masa stadia larva (Sheppard et al, 1992 ; Riniatsih et al, 2007).

Padang lamun mempunyai peranan penting dalam menjaga keseimbangan ekosistem di perairan laut. Salah satu fungsi fisik padang lamun adalah sebagai pendaur ulang zat hara di perairan. Aktivitas mikroorganisme pengurai mengembalikan bahan anorganik ke perairan melalui proses dekomposisi dari bahan organik atau jaringan hidup yang berupa detritus serasah lamun. 
Keberadaan bahan anorganisk sebagai nutrien atau zat hara ini sangat dibutuhkan oleh lamun untuk proses produksi selanjutnya ((Larkum et al, 1989 : Nybakken, 1993) ; dan Riniatsih et al (2000).

Kondisi habitat padang lamun sangat dipengaruhi oleh beberapa parameter hidro- oseanografi perairan di sekitar habitat hidup lamun. Parameter perairan yang berpengaruh terhadap pertumbuhan lamun adalah kondisi fisika, kimia dan biologi perairan. Parameterparameter tersebut antara lain berupa: suhu perairan, kecepatan arus, kecerahan, salinitas perairan, dan fraksi substrat dasar. Kondisi perairan yang sangat mempengaruhi kerapatan jenis lamun adalah fraksi substrat serta kandungan nutrient atau zat hara substrat dasar tempat lamun tumbuh. Hal ini dikarenakan adanya pemanfaatan nutrient terlarut di perairan dan nutrient yang berada di substrat dasar yang sangat dibutuhkan lamun untuk proses produksi. Nutrien tersebut diserap oleh lamun melalui daun dan system perakaran lamun yang sudah mempunyai fungsi yang berkembang sangat baik ( Tomascik et al., 1997 ; Riniatsih et al, 2001). Selanjutnya Minerva (2014) menjelaskan bahwa terdapat hubungan yang kuat antara kerapatan lamun dan kualitas air di perairan Kepulauan Karimunjawa.

Selain itu kerapatan jenis lamun sangat tergantung dari fraksi substrat serta kondisi kimia zat hara substrat dasar tempat lamun tumbuh ( Tomascik et al., 1997). Hasil penelitian yang telah dilakukan oleh Riniatsih et al, (2001) menunjukkan bahwa substrat dasar yang didominasi oleh lumpur berpasir dengan kandungan hara yang tinggi di perairan sekitar mangrove lebih banyak disukai oleh lamun spesies Enhalus acoroides dan daerah dengan substrat pasir berlumpur lebih disukai lamun spesies Thalassia hemprichii di perairan Demeling Mororejo. Sedangkan habitat dengan substrat pasir halus lebih banyak disukai oleh lamun spesies Halodule uninervis, $H$. pinifolia dan Syringodium isoetifoium di Lokasi Bandengan (Riniatsih et al, 2007) $\begin{array}{crrr}\text { Perairan } & \text { Teluk } & \text { Awur sebagai } \\ \text { perairan } & \text { pesisir } & \text { mempunyai }\end{array}$ keanekaragaman jenis lamun yang relative tinggi. Namun dengan berjalannya waktu dan banyaknya aktivitas manusia yang memanfaatkan lokasi tersebut, dikhawatirkan akan berdampak pada kelestarian padang lamun di dalamnya. Pembangunan di daerah pesisir, banyaknya masukan bahan organik dari daratan, aktivitas perahu nelayan, aktivitas pengunjung wisata pantai, dan perubahan pola arus yang membawa timbunan sedimen dapat mempengaruhi keberadaan lamun di perairan tersebut. sumber nitrat dan phosfat sebagai nutrient di perairan yang berasal dari hasil dekomposisi oleh organism pengurai dan hasil masukan dari daratan diduga dapat mempengatuhi keberadaan dan keanekaragaman lamun di perairan tersebut. Untuk itu perlu dilakukan penelitian ini dengan tujuan untuk :mengetahui distribusi jenis lamun berdasar pada sebaran nutrient perairan di lamun perairan Teluk Awur Jepara.

\section{MATERI DAN METODE}

Materi yang digunakan dalam penelitian ini adalah sampel air laut dan substrat dasar yang diambil pada beberapa lokasi penelitian di padang lamun perairan Teluk Awur. Pada penelitian ini yang diamati adalah kandungan nitrat dan phospat pada kolom air dan pada substrat dasar. Selain materi utama tersebut di atas, juga dilakukan pengambilan data untuk mengtahui kerapatan lamun, \% Penutupan lamun, struktur kuomunitas lamun dan beberapa parameter hidrooseanografi perairan, yang antara lain meliputi suhu perairan, kecerahan, kedalaman, salinitas, kecepatan arus, oksigen terlarut, dan kandungan bahan organik substrat dasar.

Metode yang digunakan dalam penelitian ini adalah studi kasus dan cara pengumpulan data dengan menggunakan sample survey method, yaitu metoda pengumpulan data dengan cara pengamatan terhadap sebagian populasi yang hasilnya diharapkan dapat 
menggambarkan sifat populasi dari obyek penelitian, sehingga dapat digunakan untuk menggambarkan suatu pupolasi di suatu habitat pada waktu tertentu (Mulyani, 1988)

Lokasi penelitian ditentukan secara Purposif, yaitu penentuan titik sampling dengan terlebih dahulu melalui beberapa pertimbangan. Pertimbangan penentuan lokasi didasarkan pada distribusi jenis lamun. Lokasi penelitian meliputi perairan padang lamun di Teluk Awur Jepara yang terbagi menjadi empat stasium. Masingmasing stasiun dibagi menjadi tiga sub stasiun ( Derrmaga sebagai Stasiun I: I.1, I.2 dan I.3; daerah sekitar mangrove sebagai Stasiun II:: II.1., II.2 dan II.3 ; lokasi sekitar lapangan sebagai Stasiun III yang terbagi menjadi ; III.1, III.2 dan III.3).dan belakang asrama mahasiswa sebagai Stasiun IV yang terbagi IV1, IV2, IV3 dan IV4). Pengambilan sampel lapangan dilakukan selama bulan Mei 2012, dengan pengulangan 3 kali ulangan untuk setiap sub stasiunnya,

Penghitungan kerapatan dan \% penutupan lamun dilakukan dengan metoda line trnsect dengan pendekatan estimasi dari metoda Saito dan Atobe (English et al, 1997). Pengambilan sampel air laut dan sedimen substrat dasar dilakukan dengan menggunakan botol sampel dan sediment core di masingmasing stasiun penelitian. Sampel yang sudah diambil dimasukkan ke dalam cool box untuk diawetkan. Selanjutnya sampel dibawa ke Laboratorium Penelitian Teknik Lingkungan Jurusan Teknik Lingkungan FT Universitas Diponegoro untuk dilakukan analisa kandungan nitrat dan phospat air dan sedimen..Selama pengambilan sampel juga dilakukan pengukuran parameter hidro-oseanografi (suhu, salinitas, kecepatan arus, kecerahan, kandungan bahan organik, oksigen terlarut dan fraksi substrat.

\section{HASIL DAN PEMBAHASAN}

Hasil identifikasi jenis lamun yang ditemukan dilokasi penelitian adalah Enhalus acoroides, Thalassia hemprichii, Cymodocea serrulata, Cymodocea rotundata, dan Syringodium isoetifolium. Rata-rata kerapatan jenis lamun di lokasi penelitian selama pengambilan sampel menunjukkan adanya perbedaan sebaran lamun di setiap sub stasiun (Tabel 1).

Prosentase penutupan lamun selama penelitian menunjukkan bahwa penyebaran lamun terkait dengan sebaran jenis substrat dasar di lokasi penelitian disajikan pada Tabel 2 berikut ini.

Tabel 1. Rata-rata Kerapatan Jenis Lamun di Lokasi Penelitian (†egakan/m²)

\begin{tabular}{lcccc}
\hline \multirow{2}{*}{\multicolumn{1}{c}{ Jenis Lamun }} & \multicolumn{5}{c}{ Stasiun } \\
\cline { 2 - 5 } & $\mathrm{I}$ & $\mathrm{I}$ & $\mathrm{III}$ & iv \\
\hline Enhalus acoroides & 6,42 & 7,67 & 19,23 & 11,13 \\
Thalassia hemprichii & 54,21 & 53,32 & 65,64 & 23,53 \\
Cymodocea serrulata & 43,25 & 36,64 & 84,43 & 0 \\
Cymodocea rotundata & 23,87 & 0 & 45,32 & 0 \\
Syringodium isoetifolium & 31,35 & 0 & 23,56 & 0 \\
\hline
\end{tabular}

Tabel 2. Prosentase Penutupan Lamun di Lokasi Penelitian (\%)

\begin{tabular}{lcccc}
\hline \multirow{2}{*}{\multicolumn{1}{c}{ Jenis Lamun }} & \multicolumn{5}{c}{ Stasiun } & IV \\
\cline { 2 - 5 } & I & II & III & 5,67 \\
\hline Enhalus acoroides & 5,42 & 3,31 & 14,67 & 13,54 \\
Thalassia hemprichii & 30,21 & 43,22 & 50,75 & 0 \\
Cymodocea serrulata & 27,25 & 26,46 & 64,34 & 0 \\
Cymodocea rotundata & 12,33 & 0 & 23,10 & 0 \\
Syringodium isoetifolium & 21,54 & 0 & 10,32 & 0 \\
\hline
\end{tabular}


Hasil analisa untuk kandungan nitrat dan phospat perairan dan sedimen selama penelitian menunjukkan variasi yang berbeda. Hasil analisa menujukkan kandungan nitrat dan phospat perairan dan sedimen tertinggi diperoleh pada sub stasiun III.

Susbstrat dasar sebagai tempat tumbuh lamun merupakan salah satu faktor pembatas bagi jenis lamun yang tumbuh di atasnya. Hasil analisa fraksi substrat dasar di lokasi penelitian disajikan pada Tabel 4 berikut ini.

Adapun hasil perhitungan struktur komunitas lamun selama penelitian menunjukkan nilai indeks Keanekaragaman, Indeks Keseragaman dan indeks Dominansi yang berbeda di setiap lokasi penelitian (Tabel 5) namun masih dalam kategori yang hampir sama, yaitu katagori rendah hingga sedang. Indeks Keanekaragaman tertinggi terlihat di sub stasiun 3 dan terendah pada sub station 4. Demikian juga untuk indeks Keseragaman dan Indeks Dominansi.

Rata-rata hasil perhitungan kerapatan lamun tertinggi terlihat di sub stasiun III, dengan 4 jenis lamun ditemukan di lokasi tersebut (Enhalus acoroides, Thalassia hemprichii, Cymodocea serrulata, Cymodocea rotundata dan Syringodium isoetifolium). Lokasi sub stasiun III merupakan lokasi pengamatan yang berdekatan dengan ekosistem mangrove sebagai lokasi replant mangrove Universitas Diponegoro di Teluk Awur. Diduga dengan adanya ekosistem mangrove di lokasi terebut banyak memberikan sumbangan nutrient yang masuk dari areal mangrove sebagai hasil dekomposisi dari serasah mangrove. Fortes (1990) dan Tomascick et al, (1997) menyampaikan bahwa sumbangan masukan nutrient dari daratan dapat memberikan tambahan nutrien yang sangat dibutuhkan oleh vegetasi lamun untuk proses produksinya.

Sedangkan lokasi dengan sebaran lamun terendah terlihat di lokasi sub stasiun IV yang hanya ditemukan dua spesies lamun, yaitu Enhalus acoroides dan Thalassia hemprichii. Demikian juga untuk \% Penutupan lamun. Lokasi sub stasiun IV merupakan sub stasiun yang terletak di belakang asrama mahasiswa, yang merupakan lokasi yang berdekatan dengan area wisata. Banyaknya kunjungan wisata lokal dan aktivitas pemancingan oleh penduduk sekitar Teluk Awur diduga merupakan salah satu faktor yang mempengaruhi kestabilan kondisi perairan yang menyebabkan rendahnya jenis dan jumlah lamun di lokasi tersebut. Fraksi substrat dasar di sub stasiun IV lebih banyak mengadung lumpur hitam dan rendahnya kandungan nutrien terlarut di perairan dan sedimen, diduga juga merupakan faktor pembatas bagi keberadaan lamun di lokasi tresebut.

Berdasarkan hasil pengukuran kandungan nitrat dan phospat di sedimen yang telah dianalisa di laboratorium menunjukan kandungan nutrient perairan dan sedimen bervariasi dengan kisaran rata-rata antara 3,006-3,276 mg/l untuk nitrat dan $0,0025 \quad-0,0076 \quad \mathrm{mg} / \mathrm{l}$ untuk phospat perairan serta 4,254-7,324 $\mathrm{mg} / \mathrm{l}$ untuk nitrat dan 2,324-5,544 $\mathrm{mg} / \mathrm{l}$ untuk phospat sedimen perairan.

Kisaran kandungan nitrat dan phospat perairan menunjukkan kisaran sedang. Menurut Monoarfa (1992), kisaran kandungan nitrat sedimen antara 3-

Tabel 3. Rata-rata Kandungan Nitrat dan Phospat Air dan Sedimen di Lokasi Penelitian (mg/l)

\begin{tabular}{|c|c|c|c|c|}
\hline \multirow{3}{*}{$\begin{array}{c}\text { Sub } \\
\text { Stasiun }\end{array}$} & \multicolumn{4}{|c|}{ Hasil Analisa Laboratorium } \\
\hline & \multicolumn{2}{|c|}{ Air } & \multicolumn{2}{|c|}{ Sedimen } \\
\hline & Nitrat & Phospat & Nitrat & Phospat \\
\hline I & 3,584 & 0,043 & 6,776 & 2.334 \\
\hline ॥ & 3,107 & 0,042 & 6,334 & 3,546 \\
\hline III & 4,276 & 0,076 & 7,324 & 4,544 \\
\hline IV & 3,006 & 0,043 & 5,345 & 2,786 \\
\hline
\end{tabular}


Tabel 4. Komposisi Substrat Dasar di Lokasi Penelitian

\begin{tabular}{ccccc}
\hline & & \multicolumn{3}{c}{ Fraksi Substrat (\%) } \\
\cline { 2 - 5 } Sub Stasiun & Lumpur & Pasir & Kerikil & Klasifikasi \\
\hline I & 20,14 & 76,42 & 3,44 & Pasir berlumpur \\
II & 12,34 & 74,48 & 13,18 & Pasir berlumpur \\
III & 6,83 & 87,65 & 5,52 & Pasir berlumpur \\
IV & 23,44 & 68.92 & 7,64 & Pasir berlumpur \\
\hline
\end{tabular}

Tabel 5. Hasil Perhitungan Indek Keanekaragaman (H'), Indeks Keseragaman (E) dan Indeks Dominansi (c) untuk Jenis Lamun selama Penelitian

\begin{tabular}{cccc}
\hline Sub Stasiun & $\mathrm{H}^{\prime}$ & $\mathrm{E}$ & $\mathrm{C}$ \\
\hline I1 & 1,1078 & 0,5436 & 0,3493 \\
I2 & 1,8755 & 0,6324 & 0,4332 \\
I3 & 1,4723 & 0,5409 & 0,1564 \\
II1 & 1,8768 & 0,5650 & 0,1236 \\
II2 & 2,1648 & 0,6832 & 0,5641 \\
II3 & 2,5583 & 0,5738 & 0,1240 \\
III1 & 2,5760 & 0,5437 & 0,6542 \\
III2 & 2,7896 & 0,4539 & 0,1314 \\
III3 & 2,6778 & 0,3569 & 0,2065 \\
IV1 & 1,2236 & 0,4423 & 0,0112 \\
IV2 & 1,5447 & 0,2231 & 0,0443 \\
IV3 & 1,6545 & 0,1123 & 0,4553 \\
\hline
\end{tabular}

10mg/l termasuk dalam kategegori sedang. Lokasi sub stasiun III padang lamun di Teluk Awur banyak dipengaruhi oleh masukan zat hara dari daratan. Adanya sungai yang mengalir di lokasi tersebut yang melewati areal mangrove sangat membatu dalam memperkaya nutrien terlarut di perairan dan sedimen di lokasi tersebut.

Hasil analisa laboratoroum untuk kandungan phospat di perairan dan kandungan phospat di sedimen di ekosistem padang lamun Teluk Awur berkisar antara nilai 4,254-7,324 mg/l untuk nitrat dan 2,324-5,544 mg/l untuk phospat sedimen perairan. kisaran ini termasuk dalam kategori relative rendah. Menurut Sulaeman (2005), kandungan phospat terlarut dalam perairan merupakan mineral yang berasal dari hasil pelapukan batuan mineral yang mengandung fosfor serta bahan organik yang berasal dari hasil dekomposisi tumbuhan sebagai aktivitas bakteri pengurai. Phospat yang terdapat di laut biasanya berasal dari hasil dekomposisi dari serasah lamun atau mangrove, serta masukan dari daratan (hasil dari pencucian tanah atas akibat erosi daratan).

Sebaran jenis lamun sangat dipengaruhi oleh substrat dasar sebagai tempat tumbuhnya. Substrat dasar di padang lamun di perairan Teluk Awur Jepara lebih didominasi oleh jenis pasir berlumpur. Kandungan lumpur di substrat dasar tersebut banyak mengandung bahan organik sebagai hasil pelapukan atau hasil dekomposisi vegetasi laut yang banyak mengandung nutrient. Thomascick et al, (1977) dan Larkum et al, (1988) menjelaskan bahwa kandungan bahan organik yang tinggi pada sediemen banyak menyumbang nutrient atau zat hara di sedimen. Kandungan nutrient yang berupa nitrat dan phospat di dalam sedimen ini dapat diserap oleh lamun melalui system perakarannya, sehingga dapat membantu proses pertumbuhan lamun. lamun jenis Thalassia hemprichii merupakan jenis lamun yang paling umum ditemukan hampir di semua 
perairan di Indonesia. Lamun jenis ini mempunyai sebaran yang paling luas, karena kemampuannya untuk dapat beradaptasi di semua kondisi perairan yang sangat tinggi (Larkum et al, 1988). Lamun jenis Cymodocea serrulata dan $C$. rotundata merupakan jenis lamun yang banyak ditemukan di habitat bersubstrat pasir halus yang kaya dengan kandungan bahan organik. Sedangkan jenis Syringodium isoetifolium banyak ditemukan di perairan dengan substrat dasar pasir berlumpur yang bercampur kerikil atau pecahan karang. Hal ini sesuai penelitian Riniatsih et al (2007) yang memperlihatkan hasil bahwa sebaran jenis lamun selain dipengaruhi oleh sebaran nutrien perairan dan sedimen juga dipengaruhi oleh jenis dan kandungan bahan organic dalam substrat dasar.

Indeks Keanekaragaman, Indeks Keseragaman dan Indeks Dominansi lamun menunjukan nilai rendah hingga sedang, bervariasi menurut distribusi jenis lamun yang ditemukan di lokasi penelitian. Nilai indeks Keanekaragaman terendah terlihat pada sub stasiun IV dengan hanya ada 2 spesies lamun yang ditemukan di lokasi tersenbut. Keberadaan lokasi yang berdekatan dengan areal wisata dan area pemancingan diduga merupakan areal yang terganggu keseimbangannya karena aktivitas para wisatawan dan aktivitas pemancingan oleh masyarakat setempat.

\section{KESIMPULAN}

Hasil pengamatan dan perhitungan jenis lamun yang diperoleh selama penelitian serta hasil analisa laboratorium sebaran nutrient perairan dan sedimen menunjukkan adanya keterkaitan antara perbedaan kerapatan lamun dan \% Penutupan lamun, Petbedaan kondisi parameter lingkungan khususnya kandungan nutrient di perairan dan sedimen menunjukkan perbedaan dan berpengaruh terhadap jumlah jenis lamun dan distribusinya di lokasi periran padang lamun Teluk Awur Jepara.

\section{DAFTAR PUSTAKA}

Adi, W. 2007. Komposisi dan Kelimpahan Larva dan Juvenil Ikan yang Berasosiasi dengan Tingkat Kerapatan Lamun yang Berbeda di Pulau Panjang Jepara. Jurnal Sumberdaya Perairan. ISSN 1978-1652. Vol 1. Edisi 1.

Chute, A.S. \& J.T. Turner. 2001. Plankton Studies in Buzzards Bay Massachusetts, USA. V. Ichtyoplankton. 1987 to 1993. Mar Ecol, Prog. Ser, 224: 45-54.

Dahuri, R. 2003. Keanekaragaman Hayati Laut. Penerbit PT. Gramedia Pustaka Utama, Jakarta XXXIII + $412 \mathrm{hlm}$.

Fortes, M.D. 1990. Seagrasses: A Resources Unknown in The Asean Region. Iclarm Education Series 5. International Center for Living Aquatic. Resources Management Manila, Philippines.

Helfman, G.S., B.B. Collete, D.E. Facey \& B.W. Bowen 2009. Diversity of Fishes: Biology, Evoluation and Ecology. $2^{\text {nd }}$. Eds. Wiley-Blacwell: John Wiley and Sons Ltd. Chichester. UK.737 pp.

Monoarfa, W.D. 1992. Pemanfaatan Limbah Pabrikgula Blotong dalam Produksi Klekap pada Tambak Berstekstur Liat (Thesis). Program Studi Pasca Sarjana, Universitas Hassanudin, Makassar.

Moriniere, E,C., B.J.A. Phollux, I. Nagelkerken, \& G.V. Velde. 2000. PostSettelment Life Cycle Migration Patterns and Habitat Preference of Coral Reef Fish that Use Seagrass and Mangrove Habitat as Nurseries. Estuarine Coastal and Shelf Science (2002) 55, 309-321. Netherlans.

Riniatsih, I., Imza Hermawan dan Sri Sedjati. 2000. Komunitas Pasca larva Udang Famili Penaeideae dan Hubungannya dengan Karakteristik Habitat di Padang Lamun Perairan Jepara. Jurnal Ilmu Kelautan. Vol 5 (19) September 2000.

Riniatsih, I., Widianingsih \& S. Sedjati. 2001. Kandungan Nutrisi Substrat Dasar dan Hubungannya dengan Distribusi Spesies Lamun di Perairan Jepara. Hasil Penelitian (Tidak dipublikasikan) Lemlit Universitas Diponegoro. Semarang.

Riniatsih, I., \& Widianingsih. 2007. Kelimpahan dan Pola sebaran 
Kerang-kerangan (Bivalvia) di Ekosistem Padang Lamun Perairan Jepara. Jurnal IImu Kelautan. Vol 12 (1) Maret 2007.

Sulaeman, 2005. Analisa Kimia Tanah, Tanaman, Air dan Pupuk. Balai Penelitian Tanah dan Pengembangan
Pertanian, Departemen Pertanian, Bogor.

Tomascick, T., A.J. Mah, A. Nontji \& M.K. Kasim Moosa. 1997. The Ecology of the Indonesia Seas. Part One. Periplus Edition (HK) Ltd., Singapore. 